\title{
3 \\ MEASURING POPULISM IN NEW ZEALAND
}

\author{
Lara Greaves and Jack Vowles
}

If populism is a coherent, underlying set of attitudes that is present in the minds and emotions of voters, it should be measurable by asking people questions in surveys (Geurkink, Zaslove, Sluiter \& Jacobs, 2019). ${ }^{1}$ Indeed, using somewhat different approaches, various efforts have been made to measure populist public attitudes within and across nations (Gidron \& Bonikowski, 2013; Norris \& Inglehart, 2019; Roodujin, 2018; see also Castanho Silva, Jungkunz, Helbling \& Littvay, 2019). In this chapter, we consider two alternative ways of measuring populism using questions from the 2017 New Zealand Election Study (NZES), some of which form part of the Comparative Study of Electoral Systems (CSES) (Module 5) (CSES, 2019) designed to measure populism, and others that are specific to the NZES. ${ }^{2}$ Following Mudde (2004), the CSES questions were principally designed to estimate exclusionary populism and comprise three core domains: antipathy towards elites, representative democracy and outgroups (Hobolt, Anduiza, Carkoglu, Lutz \& Sauger, 2016). As explained in Chapter 1 , we argue that an exclusionary form of

\footnotetext{
1 It is necessary to provide a brief note on some terminology used in this chapter (see De Vaus [2014] for further information). We aim to measure populism and authoritarianism through survey questions. In survey research and scale development, researchers aim to measure an underlying latent construct through survey questions (sometimes called 'items'). Multiple questions comprise a scale, which can be defined as a set of questions that work together to measure an underlying construct. 2 Charles Crothers contributed to an earlier version of this chapter-we acknowledge and thank him for his work and comments on the final draft.
} 
populism provides too narrow a definition, regardless of context; defining populism in such terms is even more problematic in (post)colonial societies such as New Zealand. ${ }^{3}$ Drawing on some CSES questions and other questions specific to the NZES, we instead develop two scales, following Norris and Inglehart (2019), which split populism away from authoritarianism. We then analyse scores on this measure of populism and authoritarianism across a range of demographics, to investigate who is more likely to endorse populism and authoritarianism.

\section{Populism in the Comparative Study of Electoral Systems and the New Zealand Election Study}

The CSES is a collaborative project that includes more than 60 election studies worldwide. Participating nations run the same module of questions, alongside some other core questions and demographics, to allow for the creation of a cross-national, open-access dataset. The latest module, included in the 2017 NZES, examines populism. For the purposes of the CSES module, populism was defined as 'citizens' attitudes towards political elites, majority rule and outgroups in representative democracy' (Hobolt et al., 2016, p. 3) (see Figure 3.1).

The set of 17 questions was conceptualised as a triangle. The corners represent three key aspects of populism: attitudes towards political elites, attitudes towards majority rule and representative democracy and attitudes towards the out-group (assumed to be immigrants). In the following sections, we present the questions and the percentages of participants who agreed with them, alongside a discussion of how these relate to the measurement of populism in New Zealand.

3 Some would label New Zealand as a postcolonial nation; that is, we experienced colonisation. However, many Māori academics argue that the nation is not postcolonial because Māori are still experiencing colonisation and its effects (Smith, 2012). 
Attitudes Towards Elites

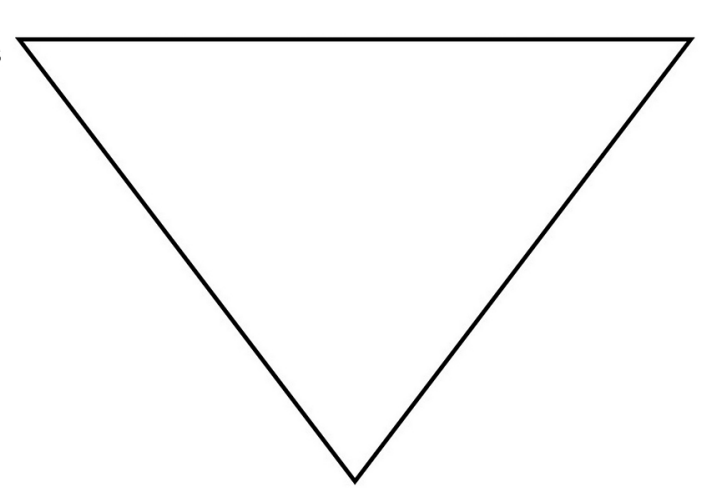

Attitudes

Towards

Out-groups
Attitudes

Towards

Majority Rule and Representative

Democracy

Figure 3.1: The components of populist attitudes.

Source: Reproduced from Hobolt et al. (2016).

\section{The Components of Populism in New Zealand?: Attitudes towards Political Elites}

A core element of exclusionary or authoritarian populism is the creation of contrast between 'us' (the pure, regular, ordinary people) and 'them' (the corrupt, untrustworthy, polluted elites) (Mudde, 2007; Mudde \& Kaltwasser, 2012). This contrast positions elites as uncaring and untrustworthy: a 'problem' for ordinary New Zealanders. To assess attitudes towards elites, participants were asked to rate the following questions on a scale from 1 ('strongly agree') to 5 ('strongly disagree'):

- 'Most politicians do not care about the people' (31 per cent agreed or strongly agreed)

- 'Most politicians are trustworthy' (in this case, 36 per cent disagreed or strongly disagreed $)^{4}$

- 'Politicians are the main problem in New Zealand' (20 per cent agreed or strongly agreed).

4 In scale development, it is best practice to include a balanced number of negatively and positively worded items, to avoid agreement bias - the tendency to agree with survey items and statements in general (De Vaus, 2014). 
One aspect of this anti-elite component of populism is the idea that, if one perceives elites as untrustworthy, it follows that they also engage in corruption. An additional question, rated on a scale of 1 ('very widespread') to 4 ('very unusual'), asked participants about the extent to which they perceive that corruption is a regular part of politics:

- 'How widespread or unusual do you think corruption such as bribetaking is among politicians and public servants in New Zealand?' (22 per cent felt it was 'very' or 'quite' widespread).

This question refers to the level of perceived corruption-here, there exists an inherent assumption that very little actual corruption occurs in many established democracies (Kaufmann, Kraay \& Mastruzzi, 2007; Zirker \& Barrett, 2017). Therefore, the question is intended to measure the perception that elites are corrupt, rather than experiences of actual corruption. Indeed, New Zealand ranks highly in the 2018 Transparency International anti-corruption index, ranking second of 180 nations (Transparency International, 2018). Despite this relatively high ranking, the level of agreement to the corruption question demonstrates that approximately one in every five participants feels that corruption is 'very' or 'quite' widespread.

Finally, a question was designed to specifically index left-wing populism (Hobolt et al., 2016), tapping into the idea that large corporations wield some control over politicians, because political elites ally with the interests of such groups rather than everyday people:

- 'Most politicians care only about the interests of the rich and powerful' (35 per cent agreed or strongly agreed).

Together, this group of questions creates an index of views regarding political elites and their role: as caring and trustworthy or uncaring 'sellouts', only interested in helping the rich and powerful. However, herein lies a problem that has been highlighted by various critics (see, e.g. Geurkink et al., 2019). Some of these questions are very close, in conceptual terms, to questions used to estimate external political efficacy. External political efficacy is defined as the sense that politicians are responsive to the demands of public opinion or, more specifically, the wishes of the person being surveyed or interviewed (Craig \& Maggiotto, 1982; Easton, 1965, 1975; Norris, 2011). If elites are indeed unresponsive, and voters perceive 
them to be so, does this make the people, by definition, populist? Further, if a specific group of voters feels particularly ignored, does this make them more populist?

Two key efforts have been made to address this potential problem: using exploratory and confirmatory factor analysis, ${ }^{5}$ researchers have found sufficient separation between sets of questions relating to external efficacy and to populism (Geurkink et al., 2019). However, this is not the case for the CSES instruments. Indeed, the efficacy question defined by Geurkink et al. is very close to the first CSES populism question listed above as part of 'attitudes to elites' ${ }^{\prime}$ and another addresses trust in politicians. In the article in question, this forms another measurable dimension that is distinct from populism. Indeed, almost all the CSES 'attitudes to elites' questions can be criticised as relating to external political efficacy. A better approach is to identify more deep-seated populist attitudes and distinguish these from short-term responses to 'representation gaps' that affect political efficacy (Kaltwasser, Vehrkamp \& Wratil, 2019). Fortunately, the CSES contains two other questions that may be used together as an alternative estimate of external efficacy (Ikeda, Kobayashi \& Hoshimoto, 2008). These ask participants to rate: (a) 'who is in power' and (b) 'voting' on a 1-5 scale, where 1 is that it will not make any difference and 5 is that it makes a 'big' difference (see Vowles, 2016).

\section{Challenges to Representative Democracy}

Another component of the CSES version of populism concerns majoritarian political values, coupled with dislike of the current system of representative democracy (Hobolt et al., 2016; Kriesi, 2014). This scale positions the 'regular people' (as opposed to the elites) as the majority, who are viewed as those who should be making the decisions in a democracy. Higher endorsement of this dimension could lead to support for changes to the system, to include a more direct link between political decisions and the people, in part by removing the power of politicians. The first

5 These are statistical techniques that allow researchers to determine which survey questions tap into the same underlying latent construct as other questions. They allow researchers to see which questions 'hang together', or have similar 'factor loadings', to create a scale (De Vaus, 2014).

6 'Politicians are not interested in what people like me think' and 'Political parties are only interested in my vote, not my opinions'. 
question can be interpreted as favouring greater use of direct democracy, rather than representative democracy (rated on a scale from 1 ['strongly agree'] to 5 ['strongly disagree']):

- 'The people, and not politicians, should make our most important policy decisions' (51 per cent agreed or agreed strongly).

This suggests that New Zealanders tend to support the use of direct rather than representative democracy and decision-making through referenda or other methods by which regular, everyday people may have their voices heard on policy matters. Work with survey data in New Zealand has shown that support for referenda has increased over time and may now be as high as 70 per cent (Bowler, Donovan \& Karp, 2007; Greaves \& Milne, 2019).?

The next question investigates the notion of compromise. In politics, particularly in a mixed member proportional (MMP) system, compromise is part of the decision-making process, whether it be with coalition partners or other groups (Church \& McLeay, 2003; McLeay \& Vowles, 2007). This question indicates the extent to which participants disagree with compromise, which inevitably moderates any ideologically motivated policy that they might support, and also tests 'anti-pluralism':

- 'What people call compromise in politics is really just selling out on one's principles' (38 per cent strongly agreed or agreed).

There also exists a question regarding protecting the rights of minorities, which is worded using very broad language that could include a range of groups. Attitudes towards minority rights have been linked to exclusionary populism; diverse groups, based on gender, sexuality, ethnicity, religion or culture, have been framed as receiving a disproportionate amount of power. In the case of New Zealand, this manifests in relation to a cisgender, ${ }^{8}$ straight, Pākehā, 'Kiwi' and secular (or Christian) majority (Plattner, 2010). However, this statement received a relatively low level of support:

- 'The will of the majority should always prevail, even over the rights of minorities' (28 per cent strongly agreed or agreed).

7 This high level of support includes favouring referendums in general, so including advisory referendums, not necessarily binding ones, both of which are features of New Zealand politics.

8 People whose gender identity matches what their culture expects their gender to be, based on their biological sex at birth. 
Populists may also wish to bypass traditional representative democracy via a strong leader who can act as a conduit between the will of the people and political decisions (Canovan, 1999; Gidron \& Bonikowski, 2013; Ionescu \& Gellner, 1969). This hypothetical strong leader would possess the power to override typical policy processes and ignore other politicians and the media (Hobolt et al., 2016; Kriesi, 2014). A notable recent example of this is Donald Trump's announcements of policy, and various other communications, via Twitter (Norris \& Inglehart, 2019). The survey asked a question regarding support for the idea of such a strong leader, rated on the same 1 ('strongly agree') to 5 ('strongly disagree') scale:

- 'Having a strong leader in government is good for New Zealand, even if the leader bends the rules to get things done' ( 43 per cent agreed or strongly agreed).

These results are striking; however, they should be interpreted with some caution. This question is double-barrelled: it indicates support for both a strong leader in government and a leader who bends rules. Therefore, some people may have disagreed regarding rule-bending but nevertheless selected 'agree' due to their strong desire for a strong leader. Regardless of how people read this question, the results indicate that nearly half the participants feel that such a leader would be a good thing for New Zealand.

\section{Attitudes towards Outgroups}

Finally, to create the 'pure' authentic, real people under the CSES working definition of populism, there exists a dimension of opposition towards 'the other', the out-group (Hobolt et al., 2016). However, besides excluding those 'elites' (investigated in the first dimension), the out-group must be defined. This is where the CSES approach to populism encounters the greatest difficulty in the New Zealand context. The classic outgroup targets of populism are generally immigrants, particularly those from ethnic minority groups, religions or cultures that are viewed as distant from, or threatening towards, the majority (Mudde \& Kaltwasser, 2012; Norris \& Inglehart, 2019; Zaslove, 2008). However, how does this component of the scale, or working definition, fit in the context of a vocal, indigenous minority? In the New Zealand context, many of these questions lack applicability because they mix concepts. 
To use a cliché, New Zealand is a land of immigrants, at least relative to most European nations. The majority group in New Zealand (European, also called Pākehā) only became the majority approximately six to seven generations ago (in about 1860). Indeed, many Pākehā are more recent immigrants than this (Phillips, 2015). As of the 2018 New Zealand Census, people of European descent comprise the majority of the population (70.2 per cent), followed by indigenous Māori peoples ( 16.5 per cent), those of Asian descent (15.1 per cent; largely those of Chinese, Filipino and Indian ethnicities), Pacific peoples (8.1 per cent; more than twothirds of whom are New Zealand-born) and other ethnicities such as Middle Eastern, African and Latin American peoples (2.7 per cent). The 2018 Census also showed that 27 per cent of the population were born outside New Zealand (Statistics New Zealand, 2019).

There is still considerable debate regarding New Zealand national identity and the extent to which it includes elements of Māori versus European cultures (biculturalism) and/or multiculturalism (see, e.g. Bell, 2009, 2014; McIntosh, Liu, McCreanor \& Teaiwa, 2005). For the CSES definition of populism to gain leverage, national identity must be defined in such a way that distinguishes between insiders and outsiders (Hobolt et al., 2016). In the broader literature, this component of populism has been called 'nativism'; this is yet another concept that is difficult to define. In one line of thinking, nativism has been defined as opposition to minority groups within one's country due to their foreign connections (Higham, 2002). However, Mudde has described nativism as 'an ideology which holds that states should be inhabited exclusively by members of the native group' (2007, p. 19). There are clear problems with applying the concept of nativism to New Zealand, where the majority group have colonised an indigenous group that still comprise a large, vocal and politically conscious minority. Therefore, a problem is posed regarding defining 'the other'.

Many of the questions in this scale domain could be understood by respondents as a reference to outsiders or ethnic minority groups. However, others more specifically mention 'immigrants' (again, rated on a five-point agreement scale):

- 'New Zealand culture is generally harmed by immigrants' (22 per cent strongly agree or agree)

- 'Immigrants increase crime rates in New Zealand' (16 per cent strongly agree or agree)

- 'Immigrants are generally good for New Zealand's economy' (reverseworded; 15 per cent disagreed/strongly disagreed). 
The results demonstrate that a minority, albeit a substantial minority, of participants (15-22 per cent) are comfortable expressing explicit prejudice towards immigrants to New Zealand. It should be noted that this attitudinal dimension is usually difficult to measure. Asking people to indicate agreement with such explicit statements underestimates the prevalence of these views due to social desirability bias. ${ }^{9}$ People struggle to accurately estimate their own prejudice; a degree of implicit or unconscious bias is evident in the majority of people (for a summary that is relevant to New Zealand, see Blank \& Houkamau, 2017). Therefore, this set of questions likely underestimates anti-immigrant prejudice.

In developing the populism scale, Hobolt et al. (2016) note that, across nations, the most visible and controversial out-group is immigrants (Zaslove, 2008). The questions allow the participants to transpose their own ideas of who the 'immigrants' are onto the question. Most immigrants to New Zealand comprise those from the 'Anglosphere' (Australia, the United Kingdom and the United States) and Europe (Ministry of Business, Innovation and Employment, 2016). While some negativity exists regarding English 'Pommie' immigrants, ${ }^{10}$ it is usually comparatively inoffensive (NZPA, 2010). Scores on this dimension are more likely to indicate prejudice towards immigrants from regions viewed as having cultures dissimilar to New Zealand (e.g. Asia, India and the Middle East). International testing of these questions has suggested that endorsement of these statements is related to prejudice towards Muslim immigrants, in particular (Hobolt et al., 2016). Further, in support of these international findings, past national survey research has shown that New Zealanders hold more anger and less warmth towards Arabs and Muslims, as compared to other groups (Shaver, Sibley, Osborne \& Bulbulia, 2017; Shaver, Troughton, Sibley \& Bulbulia, 2016).

While these first questions aim to detect direct, explicit prejudice towards immigrants, other components (of the attitudes towards out-groups questions) involve positioning national identity and what immigrants (or others) must do to be a 'New Zealander'. Exclusionary populists wish to create a solid, national in-group identity, one that cannot be penetrated by outsiders/immigrants. However, the existence of a relatively large and

9 'Social desirability bias' is the idea that people want to present themselves in a positive light, even in an anonymous questionnaire (De Vaus, 2014).

10 The term 'Pommie' is also found in South Africa and Australia-its origins are a contraction of 'pomegranate', referring to the tendency of light-skinned people to suffer from acute sunburn. 
vocal indigenous group problematises the position of nativists. The New Zealand national identity-the 'we' that populists attempt to define-is altered by the (post) colonial context and the existence of a clear indigenous minority group, members of which can assert a more authentic claim to the national identity than those descended from later colonists. Indeed, work on implicit association tests has shown that Pākehā New Zealanders equally associate Pākehā and Māori symbols and faces to New Zealand, whereas this was not the case in Australia with Indigenous Australians (Sibley \& Barlow 2009; Sibley, Liu \& Khan, 2008).

Past research has documented several strategies that New Zealand nativists have used to claim the 'New Zealand' identity. For example, some adopt a superordinate 'New Zealander' category that includes certain tokenistic aspects of Te Ao Māori (the Māori world) but not those more confronting or demanding aspects such as reparations for past injustices (Sibley, 2010). Symbolically, many embrace Māori culture as part of the national identity with the use of the haka (ceremonial dance) in sports games or a pōwhiri (welcome) to greet international guests. However, support for Māori reparations by way of claims to redress past injustices is much weaker; for example, in the 2017 NZES, 33 per cent of eligible voters were opposed to legal recognition of the Treaty of Waitangi. Some opponents of recognition of Māori rights seek to fast track the claims settlement process while framing it as the 'Treaty-grievance industry' (Barnes et al., 2012; Sibley 2010; Smith \& Abel, 2015; see also Chapter 7). Such opponents argue against claims to Māori sovereignty and self-determination and continue to repeat calls to abolish the Māori electorates. The conservative Pākehā approach, as explained in Chapter 1, is to postulate the existence of only 'one nation' or 'one people', folding Māori into a superordinate, inclusive New Zealander or 'Kiwi' category. Examples of people classifying themselves into the superordinate 'New Zealander' category may be observed in the inaugural parliamentary speeches of Mãori members of parliament (MPs) Winston Peters and Simon Bridges (Bridges, 2010). Another example is the 2006 national census controversy, in which 430,000 people (11.1 per cent of the population) identified with the 'New Zealander' label regarding their ethnicity; later analyses showed that almost all of these were of Pākehā descent (Kukutai \& Didham, 2009). A universal scale of populism is unlikely to draw out this complexity.

These issues surrounding national identity mean that it is difficult to conceptualise a national identity with standardised comparative questions. In the NZES, we used modified versions of the CSES questions. 
We measured the extent to which people believe that 'to be a true New Zealander it is important' to abide by the following four statements (rated on a 1 ['very important'] to 4 ['not important at all'] scale):

- 'To have been born in New Zealand' (47 per cent rated this as 'fairly' or 'very' important)

- 'To have Māori ancestry' (13 per cent rated this as 'fairly' or 'very' important)

- 'To be able to speak English OR Māori' (75 per cent rated this as 'fairly' or 'very' important)

- 'To follow New Zealand customs and traditions' (80 per cent rated this as 'fairly' or 'very' important).

The results suggest that those who rated New Zealand birth and/or Māori ancestry as important view immigrants as not fully meeting the criteria of a 'true New Zealander', thereby rendering them less strongly identified with the 'New Zealander' in-group. Endorsement of these ideas constitutes what has been called nativism, or a preference for people born/from here. However, translation of these concepts into the New Zealand context is problematic. Both Māori, as tangata whenua (people of the land), and tauiwi (those without iwi-non-Māori) may feel as though they are from New Zealand; most New Zealand-born Pākehā have no citizenship rights other than in New Zealand and some can claim New Zealand descent over several generations. It would have been difficult to word the third question in such a way as to make sense to participants regarding the nature of ' $\mathrm{New}$ Zealand ancestry'. Thus, we aimed to investigate the Pākehā heritage side of 'New Zealand ancestry' with an additional question. Averaged together with the Māori ancestry question, this possibly gives the most accurate representation of this aspect of nativism:

- 'For one's grandparents to have been born in New Zealand' (26 per cent rated this as 'very' or 'fairly' important).

Leaving aside debates regarding what exactly constitutes New Zealand customs (Bell, 2009, 2014; McIntosh et al., 2005), the final question of this component asks whether minorities should assimilate. Unlike questions relating to in-group exclusivity, these are both components of national identity that may be attained, albeit with some effort, by immigrants (Humpage \& Greaves, 2017): 
- 'Minorities should adapt to the customs and traditions of the majority' (38 per cent 'strongly agreed' or 'agreed').

Again, in the New Zealand context, it is unclear how this question would be read by participants. The Pākehā majority could read 'minorities' as relating to both Māori and immigrants. Populist rhetoric in New Zealand has often targeted Māori. This question was placed in the questionnaire before questions on immigrants, which may have helped to mitigate the conflation; however, it is still unclear whether this means one group (Māori), the other (immigrants) or both.

To test how this scale 'fits' the New Zealand context (statistically), we conducted an exploratory factor analysis on the CSES populism questions. On CSES-based assumptions, there would be three underlying factors; however, using the NZES data, we found five-the attitudes towards out-groups questions split into three (see Table A3.1). We present a visual representation of this in Figure 3.2. One of these factors contained the immigration-related questions; another included the questions relating to certain aspects of being a 'true New Zealander' that were unobtainable to immigrants, such as being born in New Zealand, having grandparents born here and having Māori ancestry (we can call this 'in-group exclusivity' or simply nativism). A final factor-cultural adaptation or conformity—related to those aspects of being a 'true New Zealander' that were obtainable for more recent migrants: following 'New Zealand customs and traditions' (whatever they are) and being able to speak English or te reo Māori (the Māori language). In summary, New Zealand presents an intriguing case in relation to out-group attitudes; we await further analysis of how these questions fit other colonised countries when CSES data are collected and become available. Some preliminary evidence is already available: compared to six alternative scales, the CSES populism scale rates high on internal coherence and external validity but low on conceptual breadth and cross-national validity-the latter is a concern, given the comparative purpose of the CSES (Castanho Silva et al., 2019). Meanwhile, the CSES anti-elitist populism scale correlates (weakly) at $\mathrm{r}=-0.21$, with a scale comprising the two external efficacy questions discussed earlier. 


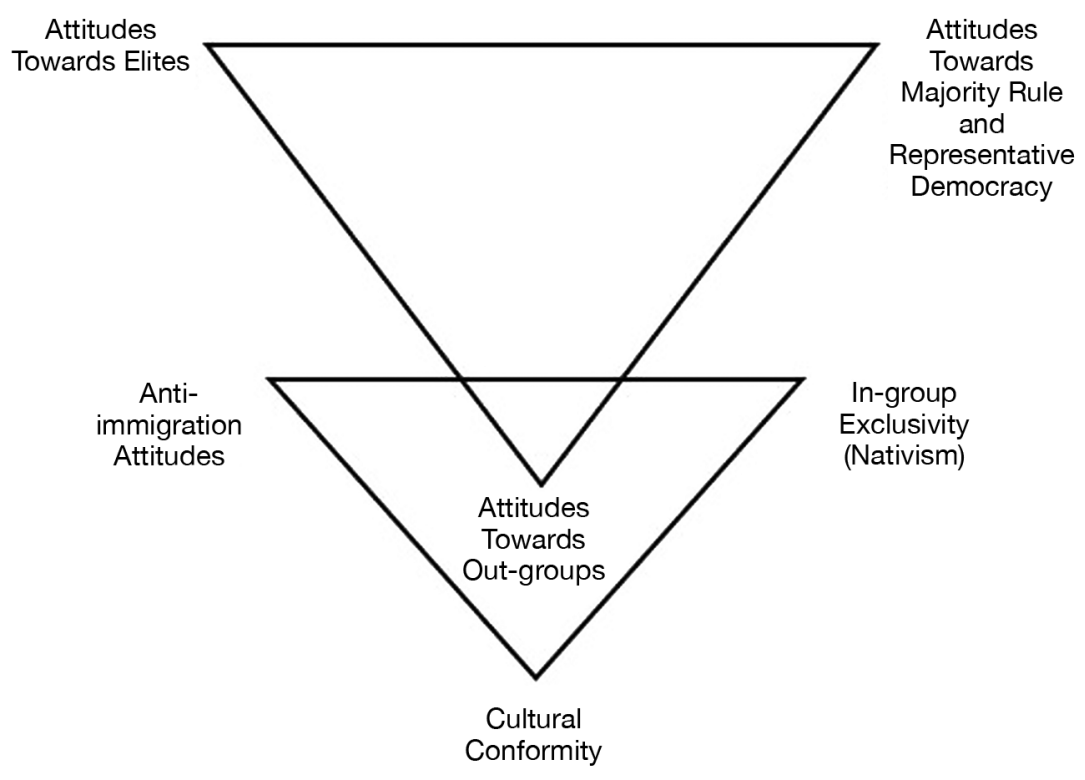

Figure 3.2: Five-factor structure underlying the CSES questions in the NZES.

Source: Adapted and modified from Hobolt et al. (2016).

Given this, our ability to compare across countries is questionable. From the first release of the CSES Module 5, available at the time of writing, there were 13 other countries for comparison: eight European (Austria, Germany, Greece, Hungary, Ireland, Italy, Lithuania and Montenegro), three Asian (Hong Kong, South Korea and Taiwan), one North American (the United States) and one South American (Chile) nation (CSES, 2019).

In our analysis of these data, based on the scales discussed above, New Zealand scored lowest (was the least apparently populist) on two of the three dimensions: anti-elite attitudes and attitudes to 'out-groups'. The 'outgroup' finding is as expected; defining who is 'out' or 'in' is more difficult in New Zealand than elsewhere. The anti-elite finding is reinforced by longitudinal analysis of external political efficacy in New Zealand, which has continued to improve following a trough in the early 1990s (Vowles, 2018); however, this simply underpins our earlier scepticism regarding at least one instrument included in the scale. New Zealand also scored second lowest on negative attitudes to representative democracy. This is despite high levels of support for direct democracy in New Zealand and a relatively high desire for strong leadership. In summary, there are many weaknesses associated with using the CSES populism scale in the New 
Zealand context and, indeed, elsewhere. There are more appropriate ways to conceptualise populism in New Zealand. We now move on to attempts to generate scales more consistent with our own theory, following the approach of Norris and Inglehart (2019), which separates populism and authoritarianism.

\section{Populism and Authoritarianism}

Critical examination of populist theory in Chapter 1 and the empirical analysis presented above both confirm that an alternative operationalisation of the concept is required. As noted previously, it is necessary to isolate exclusionary (anti-immigrant) components, particularly in the New Zealand context. Norris and Inglehart develop separate estimates of authoritarianism and populism, defining populism as 'a style of rhetoric reflecting first-order principles about who should rule, claiming that legitimate power rests with "the people" not the elites' (2019, p. 4). They define authoritarianism as 'a cluster of values prioritising collective security for the group at the expense of liberal autonomy for the individual' (p. 7). We now present questions that could be used as proxy measures for these concepts, drawing on those included in the 2017 NZES. We present the source (either CSES or NZES) and the percentage of participants who agreed or strongly agreed with the question in parentheses.

\section{Populism}

We estimated populist attitudes from six questions that position 'the people' as the legitimate source of power, versus 'the elites'. These were drawn from three CSES questions and three questions specific to the $\operatorname{NZES}(\alpha=0.74):^{11}$

- 'The people, and not politicians, should make our most important policy decisions' (CSES; 51 per cent strongly agreed or agreed)

- 'Most politicians care only about the interests of the rich and powerful' (CSES; 35 per cent strongly agreed or agreed)

- 'How widespread or unusual do you think corruption such as bribetaking is among politicians and public servants in New Zealand? (CSES; 22 per cent selected 'very' or 'quite' widespread)

11 This estimate is derived from a Cronbach's Alpha test. Generally, a score of 0.7 or above is considered to indicate that an index reliably captures an underlying dimension. 
- 'What people call compromise in politics is really just selling out on one's principles' (CSES; 38 per cent strongly agreed or agreed)

- 'The New Zealand Government is largely run by a few big interests' (NZES; 40 per cent strongly agreed or agreed)

- 'Where 1 means government should listen more to experts and 5 means government should listen more to the public, where would you put your view?' (NZES; 43 per cent selected 4 or 5 , indicating that they believe that government should listen to the public more).

As previously examined during exploration of the CSES dimensions, we note that several of these questions still overlap with external efficacy; therefore, they could be estimating either short-term perceptions generated by a highly unpopular government or other group-defined perceptions of elite unresponsiveness. Indeed, our scale based on these populism questions correlates at $r=-0.15$ (weakly) with a scale based on the two efficacy questions, a better separation than that of the equivalent CSES instrument. That scale also clearly appears as a separate factor when added to our analysis - that is, as based on the two "who is in power/ voting makes a difference' questions discussed earlier.

\section{Authoritarianism}

Next, we estimated authoritarianism from six questions $(\alpha=0.72)$ that prioritise group cohesion and conformity and seek collective security over individual (and minority) rights and freedoms.

This scale related, in part, to the desire for a strong leader:

- 'Having a strong leader in government is good for New Zealand, even if the leader bends the rules to get things done' (CSES; 43 per cent strongly agreed or agreed)

- 'A few strong leaders could make this country better than all the laws and talk' (NZES; 51 per cent strongly agreed or agreed).

Another two questions investigated attitudes towards majority rule:

- 'The will of the majority should always prevail, even over the rights of minorities' (CSES; 28 per cent strongly agreed or agreed)

- 'Minorities should adapt to the customs and traditions of the majority' (CSES; 38 per cent strongly agreed or agreed). 
Last, we included questions regarding harsh punishment for breaking rules:

- 'The death penalty should be brought back for some murders' (NZES; 40 per cent strongly agreed or agreed)

- 'What young people need most of all is strict discipline by their parents' (NZES; 54 per cent strongly agreed or agreed).

Since their development nearly 70 years ago, definitions and operationalisations of authoritarianism have been the subject of much debate (Adorno, Frenkel-Brunswik, Levinson \& Sanford, 1950; MacWilliams \& Tillman, 2016). There exists general agreement that authoritarianism is characterised by a strong desire to maintain social order and conformity, at the expense of individual autonomy. One consistent way that this has been investigated is by the centring of measurement on attitudes to child-rearing practices (Feldman, 2003; Feldman \& Stenner, 1997; Stenner, 2005). Disagreement emerges regarding measurements that include attitudes that may be endogenous to what authoritarianism is supposed to explain, such as support for the death penalty (as included in the scale being used here). However, our selection of questions compares favourably to those recently used by the British Election Study (BES) and justified as useful, if not ideal (MacWilliams \& Tillman, 2016). It may be noted that, like ours, the BES questions also encounter the issue of agreement bias (De Vaus, 2014).

Generally, political psychology research in New Zealand has measured authoritarianism with the right-wing authoritarianism (RWA) scale (Altemeyer, 1981, 1988, 2007), as part of a body of work driven by social psychologists working on the dual process model of ideology and prejudice (Duckitt, 2001; Duckitt \& Sibley, 2010). The model analyses the personal and contextual factors that predict prejudice, including RWA. A body of work using a short-form version of the scale has emerged from the New Zealand Attitudes and Values Study, including exploring the predictors of RWA and demonstrating how authoritarianism relates to out-group prejudice in the New Zealand context (see e.g. Brune, Asbrock \& Sibley, 2016; Duckitt \& Sibley, 2016; Satherley \& Sibley, 2018; Sibley et al., 2019). 
Although we operationalise authoritarianism in a slightly different way, the scales broadly tap the same underlying construct-being motivated by a desire to maximise social conformity. Since the 1990s, the NZES has included three questions that measure authoritarian attitudes, included in the scale explained earlier. Authoritarian attitudes have been particularly useful in explaining opposition to the MMP electoral system (Lamare \& Vowles, 1996). Therefore, past work from other New Zealand studies in the area of authoritarianism may inform our analysis. However, we are aware of no past work that has assessed populism in New Zealand voters as an attitudinal construct. Related work has investigated demographic and political differences between supporters of New Zealand First or related constructs such as nationalism, patriotism or different aspects of the New Zealand identity (e.g. Greaves et al., 2015; Humpage \& Greaves, 2017; Osborne, Satherley, Yogeeswaran, Hawi \& Sibley, 2019; Satherley, Yogeeswaran, Osborne \& Sibley, 2019).

Our factor analysis supports the theoretical expectation that populism and authoritarianism are distinct dimensions. The three-factor outgroups dimensions also remain distinct in our alternative NZES approach (see Table A3.2). We expected them to be significant, particularly for opinion on immigration (see Chapter 5). However, populism and authoritarianism do correlate moderately $(r=0.28)$. In other words, a simple linear regression indicates that an extreme authoritarian is likely to be 0.25 higher on the $0-1$ populism scale than an extreme liberal, with a constant term of 0.38 , which indicates the extent to which the most liberal person is closer to the elitist than the populist end of the dimension. However, the variance explained is only approximately 8 per cent. Therefore, we argue that, while these two scales of populism and authoritarianism could be improved, they represent a better conceptualisation of these constructs than the CSES model and, therefore, the best possible version, given that we are limited by those questions present in the 2017 NZES. Nonetheless, these weaknesses present opportunities to continue developing questions for later iterations of the study. 


\section{Social and Demographic Correlates of Populism and Authoritarianism}

Finally, we turn to the socio-demographic correlates of populism and authoritarianism in New Zealand. ${ }^{12}$ The multivariate analyses below use ordinary least squares regression to control for the independent effects of the different variables on populism and authoritarianism. To use an example, we may find that residents of major urban centres are less populist than those outside them; however, the effects may simply be driven by a third variable, such as higher average level of education. Therefore, we analysed each of the following while also controlling for each of the variables in each analysis: generation (war and interwar, baby boomer, generation X, millennial or generation Z), gender (binary: women or men), LGBT+ (identifying as gender- or sexuality-diverse), ethnicity (Māori, Asian or Pasifika, allowing for multiple identities), occupational type (nonmanual, manual labour or farmer), assets owned (no assets, low-risk assets or high-risk assets), household income in quintiles, whether someone reported a religious denomination, whether they lived in a major urban area (an area with population over 100,000) and education (whether they held a university degree). We only briefly discuss gender and Mãori ethnicity because they are addressed in greater detail in Chapters 6 and 7, respectively. Table A3.3 displays the coefficients and other details of the model.

We report the data here in Figure 3.3. Each bar represents the probabilities that the average person in the group in question will be populist (in the first panel) and authoritarian (in the second), where the least populist/ authoritarian person scores 0 and the most scores 1 . It also displays 95 per cent confidence intervals.

12 Throughout this work, we have replaced missing data (when people did not answer the question or selected the 'don't know' option) with the neutral/scale mid-point response to the question (where such mid-points exist). While we cannot know how these participants truly scored on the measures (although a 'don't know' response can be argued to imply neutrality or at least indifference), we have taken this standard approach for missing data throughout this chapter and the book as a whole. Including 'don't know' responses, the questions had rates of missing data between 6 per cent $(n=214$; for the question regarding government listening to experts versus the public) and 16 per cent $(\mathrm{n}=$ 556; for the question regarding whether government is run by big interests); however, the rate of missing data was at the lower end of this range for most questions. We re-ran the model reported below, dropping all cases with missing values on the populist and authoritarian questions - results were almost identical. 
Populism

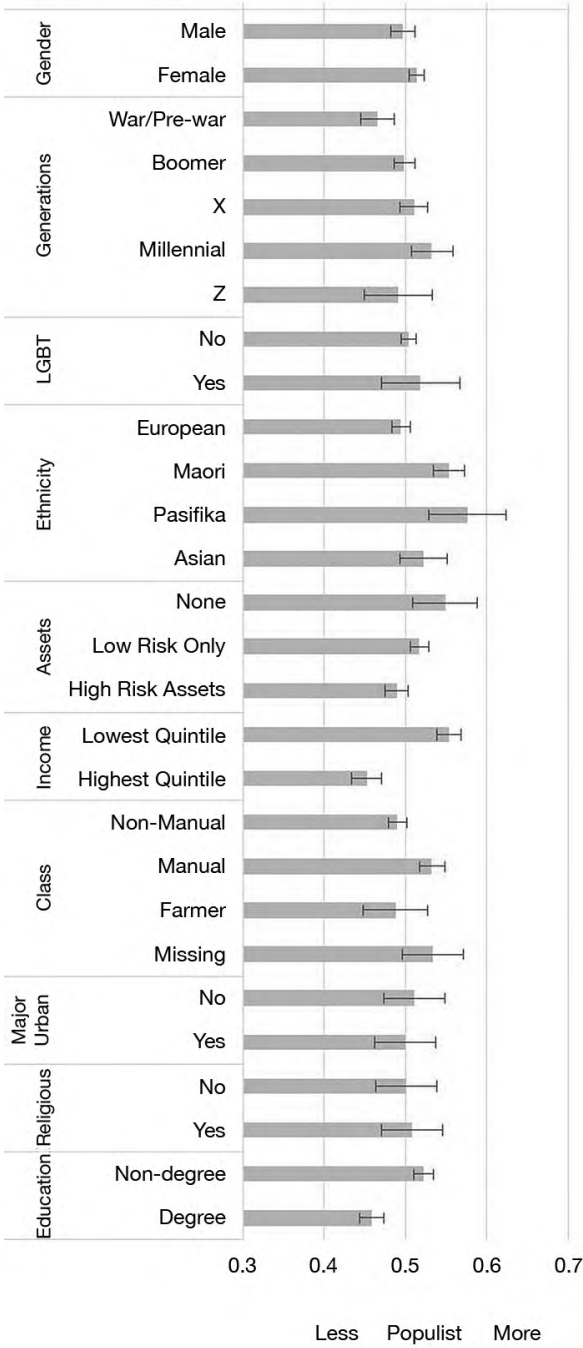

Authoritarianism

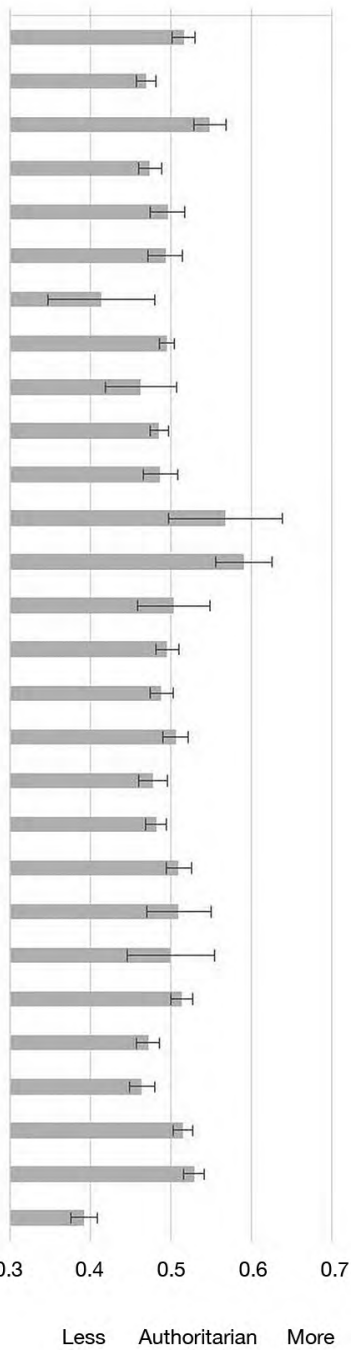

Figure 3.3: Relative probabilities of being populist and authoritarian by social groups.

Source: New Zealand Election Study (2017) (from Table A3.3). 


\section{Generational Differences}

Following the example of Norris and Inglehart (2019), participants were split into different generations: the war and interwar generation (born before 1945), baby boomers (born 1946-1964), generation X (born 1965-1979) and millennials (born 1980-1996). We also added a low number of generation $Z$ participants (born after 1997, aged 20 and under at the time of the 2017 election). In theory, older generations should be more authoritarian, whereas younger generations (generation X onwards), who came of age during times of increased protest and counterculture, should be less so (Norris \& Inglehart, 2019). However, recall that our populism questions still contain attitudes to elites often used to estimate external political efficacy. The 2017 election marked the election of the first millennial prime minister: Ardern was born in 1980. Indeed, it produced a younger cohort of MPs overall; approximately 37 per cent were under 45 years of age. This may represent a generational shift, as political elites tend to be of the older generations (James, 2018), resulting in a better relationship between elites and younger generations.

Figure 3.3 shows that the average person in the earliest generational group is expected to score 0.46 on the populist scale, compared to a millennial, who scores 0.53 . The confidence intervals for these two groups do not overlap; therefore, we can be reasonably sure that this constitutes a real difference. Indeed, this pre-1945 generation exhibits both the lowest populism and the highest authoritarianism. The generational pattern for the populism measure shows increasing propensity towards populism in recent generations, except generation $\mathrm{Z}$. However, generation $\mathrm{Z}$ had the lowest average score for authoritarianism, followed by baby boomers. The timeline for generational change in authoritarianism and populism may be different in New Zealand, as compared to other nations. Baby boomers grew up in a time of increased unrest in New Zealand, in the face of Robert Muldoon's authoritarian style of leadership (see Chapter 1). Many were coming of age in the 1970s, a period of political activism and mobilisation, in tandem with a Māori cultural renaissance (Walker, 2004): the issues spanned Māori rights, second-wave feminism, environmentalism, antinuclear campaigning and actions to support the anti-apartheid movement in South Africa. For instance, in 1981, over 150,000 people took part in protests against apartheid during the South African rugby team tour of New Zealand (Chapple, 2014). The pattern of results for populism could 
relate to the closeness of the measure to external efficacy; however, adding a control for this in an alternative version of our populist model makes almost no difference to the results.

\section{Gender and LGBT+}

In this study, gender was coded as a woman/man binary, although 12 participants ( 0.4 per cent of the sample) identified as gender diverse. Analysis of this group as a single category was undesirable due to the small sample size and the likely diversity within, so we instead folded these participants into the LGBT+ group (Lesbian, Gay, Bisexual, Transgender and further rainbow community identities). The 2017 NZES included sexual orientation for the first time. Participants could select from heterosexual or 'straight', gay or lesbian, bisexual or bi-curious, pansexual or open and asexual: for analysis, we included these categories together. It is crucial to investigate LGBT + scores on the authoritarian dimension, as the community is often a target of conservative rhetoric regarding changing values (Pappas, Mendez \& Herrick, 2009; Spierings, Lubbers \& Zaslove, 2017). As far as we are aware, no prior research has analysed populism in the LGBT+ community and very little has examined authoritariantype measures within this population (Pacilli, Taurino, Jost \& van der Toorn, 2011; Warriner, Nagoshi \& Nagoshi, 2013). We would broadly expect LGBT+ people to score lower in terms of authoritarianism, as they are less likely to endorse traditional roles and people that score higher in authoritarian measures have been shown to be more homophobic/ heterosexist (Cowie, Greaves \& Sibley, 2019; Pacilli et al., 2011).

Regarding gender, we found that women scored slightly higher in terms of populism than men, albeit well within confidence intervals. Women scored significantly lower on authoritarianism than men. Again, it may be that women are (slightly) more populist than men or, more likely, that they are lower in external efficacy. The result for authoritarianism is to be expected, given that authoritarianism is generally associated with more rigid and traditional gender roles, which may restrict women's rights (Duckitt \& Sibley, 2010). LGBT+ participants were not statistically distinguishable from heterosexual and cisgender participants regarding populism; however, as expected, they tended to be less authoritarian, although this difference was within confidence intervals. 


\section{Ethnicity}

In the American and British contexts, authoritarian populism has been identified as an 'angry white man' phenomenon (Ford \& Goodwin, 2010; Kimmel, 2017). One explanation for the rise of authoritarian populism posits such factors as decline in trust and economic power, the rise of liberal values and increased immigration. These tendencies have caused a 'cultural backlash', wherein those of European descent, especially men, become angry (Ford \& Goodwin, 2010; Kimmel, 2017; Norris \& Inglehart, 2019). According to this logic, we could expect Pākehā to exhibit higher scores on populism and authoritarianism. However, we found that those only identifying as Pākehā had the lowest average score for populism, with the average score for Asian participants being similar and Pasifika and Māori scoring highest. We also found ethnic group differences in relation to authoritarianism; Māori had a lower score, although not significantly different to that of Pākehā, whereas Asian and Pasifika populations had higher average scores. In summary, there existed minor ethnic group differences, perhaps relating to different perceptions of the responsiveness of elites in the past and differences in authoritarianism across ethnicity, which may relate to cultural differences in the construct.

\section{Socio-Economic Status}

We also investigated two variables relating to socio-economic status. In theory, those who are more vulnerable to shifts in the economic system (e.g. the automation of jobs) or those associated with globalisation (e.g. work shifting overseas) are expected to be more populist and authoritarian (Mudde \& Kaltwasser, 2012; Norris \& Inglehart, 2019). Such shifts represent a threat to their economic livelihoods. However, we tested the 'offshorability' of jobs (Blinder $\&$ Krueger, 2013) and the relative skill specificity of occupations (Iversen \& Soskice, 2001) and found no significant results when education was taken into account. Traditional occupational classifications work more effectively for this analysis; indeed, those in manual service professions have the highest average scores for both populism and authoritarianism. Assets matter little to authoritarianism; however, those with low-risk and, most of all, high-risk assets were less prone to populism. Those with high household incomes-estimated as the difference between the lowest and the highest quintiles-were both less populist and less authoritarian. Therefore, in New Zealand, working 
in a manual service profession predicts higher degrees of populism and authoritarianism, independent of education level, the offshorability of one's job or relative skill level.

\section{Religiosity and Rurality}

We expected that rural people and religious people would score higher on authoritarianism and, possibly, populism than other groups (Kimmel, 2017; Lockhart, Sibley \& Osborne, 2019; Norris \& Inglehart, 2019; Scoones et al., 2018). Further, we theorised that the higher populism of rural and religious people, as demonstrated by prior research, could have been driven by socio-economic indicators; therefore, we controlled for this in our analyses. Religious people are more likely to hold conservative values and may subscribe to authoritarianism as a 'cultural backlash' to a society that is becoming more socially liberal (Norris \& Inglehart, 2019). Those outside major urban centres may be more authoritarian due to selective migration. Prior research in New Zealand has shown that those who live in cities are more open to experience, a personality trait closely associated with liberal values (Greaves et al., 2015). Reflecting our expectations, we found that those residing outside major urban centres were likely to be more authoritarian but were not significantly more populist than their major urban counterparts. Similarly, those with a religion were no less or more populist than non-religious people but were significantly more authoritarian.

\section{Education}

Lower education levels have been a consistent predictor of populism in the international context; however, some authors have suggested that this may be due to the radical-right, exclusionary, authoritarian and nativist components of populism, rather than populism in and of itself (Rooduijn, 2018). The results of our study reflected this - those with a university degree scored lower on populism than those without one. Further, a similar pattern was found for authoritarianism. These results reflect the existing research, both nationally and internationally, showing that those with lower education tend to adopt populist or conservative, authoritarian values at higher rates than those with more education (Duckitt \& Sibley, 2016; Kimmel, 2017; Norris \& Inglehart, 2019; Satherley et al., 2019; Sibley et al., 2019). 
In summary, our investigation of populism in New Zealand reveals that baby boomers, millennials, Māori, Pasifika, manual service workers, those with no assets and people without degrees score higher on authoritarianism and populism. This is perhaps unsurprising - some of these groups may be more likely to hold a negative view of the state and elites, because they feel that the state has been insufficiently responsive to their interests; such experiences may shape feelings of low political efficacy. For some of these groups (e.g. manual service workers), this may represent a more recent shift or a type of 'cultural backlash' scenario, whereas for others, these higher scores likely represent a long history of the state being unresponsive to the group's needs (e.g. Mãori) or generational differences in political socialisation (e.g. baby boomers, millennials). In relation to authoritarianism, we found that older people tended to have higher scores, as did Pasifika and Asian participants, men, manual service workers, ruraldwellers, the religious and those without university degrees. While these scales may still be subject to limitations, the results for authoritarianism largely reflect past work using RWA scales and the results for populism represent an initial exploration of a construct not previously measured in a national study in New Zealand.

\section{Conclusion}

In this chapter, we examined the CSES model of (exclusionary) populism in New Zealand and the level of support for the various questions among NZES participants. In comparing the CSES three-dimensional model of populist attitudes across countries, New Zealand scored lowest on two of three indicators (attitudes towards elites and attitudes towards outgroups) and second lowest on the negative attitudes towards representative democracy measures. These findings suggest that, among a limited group of nations, New Zealand is relatively low in terms of populism, as defined in these terms. However, this group of nations includes the United States, Germany and Austria, where populism is recognised to be a major phenomenon. This gives support to an interpretation of the New Zealand case as one of 'exceptionalism'. However, given reservations regarding the utility of CSES instruments as a cross-national operationalisation of populism, a claim that New Zealand is exceptional would be a risky interpretation. There is more of a case for exceptionalism in terms of indigenous visibility and ethnic diversity; however, these characteristics are shared with some other countries. 
We presented an alternative approach, comprising two scales that separated populism and authoritarianism. The key disadvantage of this alternative is the loss of a comparative dimension; however, it addresses the flaw identified in CSES operationalisation. That is, collinearity between populism and external political efficacy makes it difficult to separate out short-term responses to peoples' sense of exclusion from more deep-seated populist attitudes. The NZES enables us to include an independent control variable for external efficacy; however, it may be that some of the instruments in our own populist scale are too closely associated with efficacy. The absence of a clear authoritarian-liberal dimension, except as in part summed up as 'attitudes to representation', represents another flaw in the CSES model.

In terms of age and generational experiences, some groups (but not all) demonstrated the expected differences in their levels of populism and authoritarianism. Māori and Pasifika were more populist than other ethnic groups. Baby boomers, generation $\mathrm{X}$ and millennials were more populist than the war and pre-war generation or generation $\mathrm{Z}$. All other generational groups were less authoritarian than the war and pre-war generations, with generation $\mathrm{Z}$ being the least authoritarian. However, when it came to socio-economic position and education, those in manual labour professions with no assets and lower levels of education all scored relatively high on the populism scale. Depending on social identity, some of these results are likely related to different phenomena; that is, some groups may always have had negative views towards elites, whereas for others, the results may relate to a rising discontent or 'cultural backlash'.

Broadly speaking, there appears to be no evidence for a significant populist or authoritarian mood of discontent, although New Zealanders are relatively evenly distributed across the two dimensions, with most falling in the middle. However, as illustrated by the experience of New Zealand in the 1970s and early 1980s under the Muldoon government, there exists potential for greater mobilisation of authoritarian attitudes, particularly when opinion, activism and policy turn in the other direction. Support for strong political leadership is relatively high, as is a belief in the need for strong discipline of children (both receiving approximately 50 per cent support). Authoritarian responses have remained stubbornly high since these questions were first asked in 1996. Consequently, future research must generate better estimates of populist attitudes and values, not only in New Zealand but also elsewhere. 


\section{References}

Adorno, T. W., Frenkel-Brunswik, E., Levinson, D. \& Sanford, N. (1950). The authoritarian personality. New York City, NY: Harper.

Altemeyer, B. (1981). Right-wing authoritarianism. Winnipeg, Canada: University of Manitoba Press.

Altemeyer, B. (1988). Enemies of freedom: Understanding right-wing authoritarianism. San Francisco, CA: Jossey-Bass.

Altemeyer, B. (2007). The authoritarians. Winnipeg, Canada: University of Manitoba Press.

Barnes, A. M., Borell, B., McCreanor, T., Nairn, R., Rankine, J. \& Taiapa, K. (2012). Anti-Māori themes in New Zealand journalism-Toward alternative practice. Pacific Journalism Review: Te Koakoa, 18(1), 195-216. doi.org/ 10.24135/pjr.v18i1.296

Bell, A. (2009). Dilemmas of settler belonging: Roots, routes and redemption in New Zealand national identity claims. The Sociological Review, 57(1), 145-162. doi.org/10.1111/j.1467-954X.2008.01808.x

Bell,A. (2014).Relatingindigenousandsettleridentities: Beyonddomination.London, United Kingdom: Palgrave MacMillan. doi.org/10.1057/9781137313560

Blank, A. \& Houkamau, C. (2017). REWIRE: The little book about bias. Auckland, New Zealand: Oranui Press.

Blinder A. S. \& Krueger, A. B. (2013). Alternative measures of offshorability: A survey approach. Journal of Labor Economics, 31(2), S97-S128. doi.org/ 10.1086/669061

Bowler, S., Donovan, T. \& Karp, J. (2007). Enraged or engaged? Preferences for direct citizen participation in affluent democracies. Political Research Quarterly, 60(3), 351-362. doi.org/10.1177/1065912907304108

Bridges, S. (2010). Diversity enriches the view. In M. Bargh (Ed.), Mãori and Parliament: Diverse strategies and compromises (pp. 138-141). Wellington, New Zealand: Huia.

Brune, A., Asbrock, F. \& Sibley, C. G. (2016). Meet your neighbours: Authoritarians engage in intergroup contact when they have the opportunity. Journal of Community and Applied Social Psychology, 26, 576-580. doi.org/ 10.1002/casp.2289 
Canovan, M. (1999). Trust the people! Populism and the Two Faces of Democracy. Political Studies, 47(1), 2-16. doi.org/10.1111/1467-9248.00184

Castanho Silva, B., Jungkunz, S., Helbling, M. \& Littvay, L. (2019). An empirical comparison of seven populist attitudes scales. Political Research Quarterly. doi.org/10.1177/1065912919833176

Chapple, G. (2014). When the tour came to Auckland. Wellington, New Zealand: Bridget Williams Books. doi.org/10.7810/9781927277461

Church,S. \&McLeay,E. (2003). Theparliamentary reviewofMMPin NewZealand. Representation, 39(4), 245-254. doi.org/10.1080/00344890308523231

Comparative Study of Electoral Systems. (2019, 21 May). CSES Module 5 First Advance Release [dataset and documentation]. Ann Arbor, MI: CSES.

Cowie, L. J., Greaves, L. M. \& Sibley, C. G. (2019). Sexuality and sexism: Differences in ambivalent sexism across gender and sexual identity. Personality and Individual Differences, 148, 85-89. doi.org/10.1016/j.paid.2019.05.023

Craig, S. C. \& Maggiotto, M. A. (1982). Measuring political efficacy. Political Methodology, 8, 85-109.

De Vaus, D. (2014). Surveys in social research (6th ed.). Sydney, Australia: Allen \& Unwin.

Duckitt, J. (2001). A dual-process cognitive-motivational theory of ideology and prejudice. Advances in Experimental Social Psychology, 33, 41-113. doi.org/ 10.1016/S0065-2601(01)80004-6

Duckitt, J. \& Sibley, C. G. (2010). Personality, ideology, prejudice and politics: A dual-process motivational model. Journal of Personality, 78(6), 1861-1894. doi.org/10.1111/j.1467-6494.2010.00672.x

Duckitt, J. \& Sibley, C. G. (2016). Personality, ideological attitudes, and group identity as predictors of political behaviour in majority and minority ethnic groups. Political Psychology, 37(1), 109-124. doi.org/10.1111/pops.12222

Easton, D. (1965). A systems analysis of political life. New York: Wiley.

Easton, D. (1975). A reassessment of the concept of political support. British Journal of Political Science, 5(4), 435-457. doi.org/10.1017/S0007123400008309

Feldman, S. (2003). Enforcing social conformity: A theory of authoritarianism. Political Psychology, 24(1), 41-74. doi.org/10.1111/0162-895X.00316

Feldman, S. \& Stenner, K. (1997). Perceived threat and authoritarianism. Political Psychology, 18(4), 741-770. doi.org/10.1111/0162-895X.00077 
Ford, R. \& Goodwin, M. J. (2010). Angry white men: Individual and contextual predictors of support for the British National Party. Political Studies, 58(1), 1-25. doi.org/10.1111/j.1467-9248.2009.00829.x

Geurkink, B., Zaslove, A., Sluiter, R. \& Jacobs, K. (2019). Populist attitudes, political trust and external political efficacy: Old wine in new bottles? Political Studies [Advance online publication]. doi.org/10.1177/0032321719842768

Gidron, N. \& Bonikowski, B. (2013). Varieties of populism: Literature review and research agenda (Weatherhead Working Paper Series, No. 13-0004), 1-13.

Greaves, L. M., Cowie, L., Fraser, G., Muriwai, E., Huang, Y., Milojev, P. \& Osborne, D. (2015). Regional differences and similarities in the personality of New Zealanders. New Zealand Journal of Psychology, 1, 4-16.

Greaves, L. M. \& Milne, B. (2019). Referendexit: Has support for referenda decreased since the flag referendums? Findings from a New Zealand national survey (Unpublished manuscript). University of Auckland, Auckland, New Zealand.

Higham, J. (2002). Strangers in the land: Patterns of American nativism, 1860-1925. New Brunswick, NJ: Rutgers University Press.

Hobolt, S., Anduiza, E., Carkoglu, A. Lutz, G. \& Sauger, N. (2016). Democracy divided? People, politicians and the politics of populism (CSES Planning Committee Final Report, CSES Module 5). Retrieved from cses.org/wpcontent/uploads/2019/03/CSES5_ContentSubcommittee_FinalReport.pdf

Humpage, L. \& Greaves, L. (2017). 'Truly being a New Zealander': Ascriptive versus civic views of national identity. Political Science, 69(3), 247-263. doi.org/10.1080/00323187.2017.1418177

Ionescu, G. \& Gellner, E. (Eds). (1969). Populism: Its meaning and national characteristics. London, United Kingdom: Macmillan.

Ikeda, K., Kobayashi, T \& Hoshimoto, M. (2008). Does political participation make a difference: The relationship between political choice, civic engagement and political efficacy. Electoral Studies, 27(1), 77-88. doi.org/10.1016/j.elect stud.2007.11.004

Iversen, T. \& Soskice, D. (2001). An asset theory of social policy preferences. American Political Science Review, 95(4), 875-911. doi.org/10.1017/ S0003055400400079

James, C. (2018). The first post baby boomer election. In S. Levine (Ed.), Stardust and substance: The New Zealand general election of 2017 (pp. 325-338). Wellington, New Zealand: Victoria University Press. 
Kaltwasser, C. R., Vehrkamp, R. \& Wratil, C. (2019). Europe's choice populist attitudes and voting intentions in the 2019 European election. Gütersloh, Germany: Bertelsmann Stiftung.

Kaufmann, D., Kraay, A. \& Mastruzzi, M. (2007). Measuring corruption: Myths and realities. Retrieved from openknowledge.worldbank.org/handle/10986/9576

Kimmel, M. (2017). Angry white men: American masculinity at the end of an era. New York: Nation Books.

Kriesi, H. (2014). The populist challenge. West European Politics, 37(2), 361-378. doi.org/10.1080/01402382.2014.887879

Kukutai, T. \& Didham R. (2009). In search of ethnic New Zealanders: National naming in the 2006 Census. Social Policy Journal of New Zealand, 36, 46-62. Retrieved from www.msd.govt.nz/about-msd-and-our-work/publicationsresources/journals-and-magazines/social-policy-journal/spj36/36-in-searchof-ethnic-new-zealanders.html

Lamare, J. \& Vowles, J. (1996). Party interests, public opinion and institutional preferences: Electoral system change in New Zealand. Australian Journal of Political Science, 31(3), 321-346. doi.org/10.1080/10361149651085

Lockhart, C., Sibley, C. \& Osborne, D. (2019). Religion makes-and unmakes - the status quo: Religiosity and spirituality have opposing effects on conservatism via RWA and SDO. Religion, Brain \& Behaviour [Advance online publication]. doi.org/10.1080/2153599X.2019.1607540

MacWilliams, M. C. \& Tillman, E. (2016). Authoritarianism and the rise of populist national parties in Europe: Preliminary findings from surveys of four European nations. Retrieved from static1.squarespace.com/static/50bf87bfe 4b090 fdb6237204/t/58136bd71b631bf20f10daa4/1477667800156/ EuropeanReleaseD2.pdf

McIntosh, T., Liu, J., McCreanor, T. \& Teaiwa, T. (Eds). (2005). New Zealand identities: Departures and destinations. Wellington, New Zealand: Victoria University Press.

McLeay, E. \& Vowles, J. (2007). Redefining constituency representation: The roles of New Zealand MPs under MMP. Regional and Federal Studies, 17(1), 71-95. doi.org/10.1080/13597560701189628

Ministry of Business, Innovation and Employment. (2016). Migration trends 2016/2017. Retrieved from www.mbie.govt.nz/immigration-and-tourism/ immigration/migration-research-and-evaluation/migration-trends-report/

Mouffe, C. (2018). For a left populism. London, United Kingdom: Verso. 
Mudde, C. (2004). The populist zeitgeist. Government and opposition, 39(4), 541-563. doi.org/10.1111/j.1477-7053.2004.00135.x

Mudde, C. (2007). Populist radical right parties in Europe. Cambridge, United Kingdom: Cambridge University Press.

Mudde, C. \& Kaltwasser, C. R. (Eds). (2012). Populism in Europe and the Americas. Cambridge, United Kingdom: Cambridge University Press.

New Zealand Election Study. (2017). New Zealand Election Study [dataset]. Retrieved from www.nzes.org/exec/show/data

Norris, P. (2011). Democratic deficit: Critical citizens revisited. New York: Cambridge University Press.

Norris, P. \& Inglehart, R. (2019). Cultural backlash: Trump, Brexit and authoritarian populism. Cambridge, United Kingdom: Cambridge University Press. doi.org/10.1017/9781108595841

NZPA. (2010, 6 April). 'Pommy git' okay, BSA rules. New Zealand Herald. Retrieved from www.nzherald.co.nz/nz/news/article.cfm?c_id=1 \&objectid=10636663

Osborne, D., Satherley, N. Yogeeswaran, K., Hawi, D. \& Sibley, C. (2019). White nationalism and multiculturalism support: Investigating the interactive effects of white identity and national attachment on support for multiculturalism. New Zealand Journal of Psychology, 48(1), 65-74.

Pacilli, M., Taurino, A., Jost, J. \& van der Toorn, J. (2011). System justification, right-wing conservatism and internalised homophobia: Gay and lesbian attitudes toward same-sex parenting in Italy. Sex Roles, 65(580). doi.org/ 10.1007/s11199-011-9969-5

Pappas, C., Mendez, J. \& Herrick, R. (2009). The negative effects of populism on gay and lesbian rights. Social Science Quarterly, 90(1), 150-163. doi.org/ 10.1111/j.1540-6237.2009.00608.x

Phillips, J. (2015). History of immigration. In Te Ara: The Encyclopedia of New Zealand. Retrieved from www.TeAra.govt.nz/en/history-of-immigration

Plattner, M. F. (2010). Democracy's past and future: Populism, pluralism and liberal democracy. Journal of Democracy, 21(1), 81-92. doi.org/10.1353/ jod.0.0154

Rooduijn, M. (2018). What unites the voter bases of populist parties? Comparing the electorates of 15 populist parties. European Political Science Review, 10(3), 351-368. doi.org/10.1017/S1755773917000145 
Satherley, N. \& Sibley, C. G. (2018). A dual process model of post-colonial ideology. International Journal of Intercultural Relations, 64, 1-11. doi.org/ 10.1016/j.ijintrel.2018.03.003

Satherley, N., Yogeeswaran, K., Osborne, D. \& Sibley, C. G. (2019). Differentiating between pure patriots and nationalistic patriots: A model of national attachment profiles and their sociopolitical attitudes. International Journal of Intercultural Relations, 72, 13-24. doi.org/10.1016/j.ijintrel.2019.06.005

Scoones, I., Edelman, M., Borras Jr, S. M., Hall, R., Wolford, W. \& White, B. (2018). Emancipatory rural politics: Confronting authoritarian populism. The Journal of Peasant Studies, 45(1), 1-20. doi.org/10.1080/03066150.2017. 1339693

Shaver, J. H., Sibley, C. G., Osborne, D. \& Bulbulia, J. (2017). News exposure predicts anti-Muslim prejudice. Plos One, 12(3), e0174606. doi.org/10.1371/ journal.pone.0174606

Shaver, J. H., Troughton, G., Sibley, C. G. \& Bulbulia, J. (2016). Religion and the unmaking of prejudice toward Muslims: Evidence from a large national sample. Plos One, 11(3), e015020. doi.org/10.1371/journal.pone.0150209

Sibley, C. G. (2010). The dark duo of post-colonial ideology: A model of symbolic exclusion and historical negation. International Journal of Conflict and Violence, 4(1), 106-123. doi.org/10.4119/ijcv-2818

Sibley, C. G. \& Barlow, F. (2009). Ubiquity of whiteness in majority group national imagination: Australian = white, but New Zealander does not. Australian Journal of Psychology, 61(3), 119-127. doi.org/10.1080/00049530802239300

Sibley, C. G., Bergh, R., Satherley, N., Osborne, D., Milojev, P., Greaves, L. M., ... Duckitt, J. (2019). Profiling authoritarian leaders and followers. Testing, Psychometrics, Methodology in Applied Psychology, 26, 1-17. doi.org/10.4473/ TPM26.3.6

Sibley, C. G., Liu, J. H. \& Khan, S. S. (2008). Who are 'we'? Implicit associations between ethnic and national symbols for Māori and Pākehā. New Zealand Journal of Psychology, 37(2), 38-49.

Smith, J. \& Abel, S. (2015). Ka whaw'ai tonu matou: Indigenous television in Aotearoa/New Zealand. In W. G. Pearson \& S. Knabe (Eds), Reverse shots: Indigenous film and media in an international context: Film and media studies book 17 (pp. 175-188). Waterloo, United Kingdom: Wilfred Laurier University Press.

Smith, L. (2012). Decolonising methodologies: Research and indigenous peoples (2nd ed.). London, United Kingdom: Zed Books. 
Spierings, N., Lubbers, M. \& Zaslove, A. (2017). 'Sexually modern nativist voters: Do they exist and do they vote for the populist radical right? Gender and Education, 29(2), 216-237. doi.org/10.1080/09540253.2016.1274383

Statistics New Zealand. (2019). 2018 Census totals by topic - national highlights. Retrieved from www.stats.govt.nz/information-releases/2018-census-totalsby-topic-national-highlights

Stenner, K. (2005). The Authoritarian Dynamic. Cambridge: Cambridge University Press.

Transparency International. (2018). New Zealand. Retrieved from www.trans parency.org/country/NZL

Vowles, J. (2016). Globalisation, government debt, government agency and political efficacy: A cross-national comparison. In J. Vowles \& G. Xezonakis (Eds), Globalisation and domestic politics: Parties, public opinion and elections (pp. 155-171). Oxford, United Kingdom: Oxford University Press. doi.org/ 10.1093/acprof:oso/9780198757986.003.0008

Vowles, J. (2018). Electoral systems in context: New Zealand. In E. S. Herron, R. Pekkanen \& M. S. Shugart (Eds), The Oxford handbook of electoral systems (pp. 805-824). Oxford, United Kingdom: Oxford University Press. doi.org/ 10.1093/oxfordhb/9780190258658.013.29

Walker, R. (2004). Struggle without end (2nd ed.). Auckland, New Zealand: Penguin.

Warriner, K., Nagoshi, C. T. \& Nagoshi, J. L. (2013). Correlates of homophobia, transphobia and internalised homophobia in gay or lesbian and heterosexual samples. Journal of Homosexuality, 60(9), 1297-1314. doi.org/10.1080/009 18369.2013.806177

Zaslove, A. (2008). Here to stay? Populism as a new party type. European Review, 16(3), 319-336. doi.org/10.1017/S1062798708000288

Zirker, D. \& Barrett, P. (2017). Corruption vs. corruption scandals in New Zealand: Bridging a wide gulf? Political Science, 69(1), 35-48. doi.org/ 10.1080/00323187.2017.1327798 


\section{Appendices}

Table A3.1: Item content and factor loadings for the Comparative Study of Electoral Systems populism items

\begin{tabular}{|c|c|c|c|c|c|}
\hline Item & $\begin{array}{l}\text { Anti- } \\
\text { elite }\end{array}$ & Representation & $\begin{array}{c}\text { Anti- } \\
\text { immigration }\end{array}$ & Nativism & $\begin{array}{c}\text { Cultural } \\
\text { Conformity }\end{array}$ \\
\hline $\begin{array}{l}\text { Compromise } \\
\text { a sell-out }\end{array}$ & 0.453 & 0.170 & 0.024 & 0.080 & -0.001 \\
\hline $\begin{array}{l}\text { Politicians } \\
\text { don't care }\end{array}$ & 0.777 & 0.124 & -0.037 & -0.057 & -0.006 \\
\hline $\begin{array}{l}\text { Politicians } \\
\text { trustworthy (R) }\end{array}$ & -0.489 & 0.133 & -0.011 & 0.129 & -0.025 \\
\hline $\begin{array}{l}\text { Politicians the } \\
\text { main problem }\end{array}$ & 0.716 & 0.106 & 0.013 & 0.016 & -0.013 \\
\hline Politicians corrupt & 0.470 & -0.129 & 0.153 & 0.092 & 0.023 \\
\hline People decide & 0.490 & 0.029 & 0.010 & 0.017 & 0.040 \\
\hline $\begin{array}{l}\text { Politicians care } \\
\text { for rich }\end{array}$ & 0.744 & -0.092 & 0.024 & 0.027 & -0.025 \\
\hline $\begin{array}{l}\text { Politicians care } \\
\text { for rich }\end{array}$ & 0.035 & 0.677 & 0.012 & -0.040 & 0.068 \\
\hline $\begin{array}{l}\text { Majority overrules } \\
\text { minority rights }\end{array}$ & 0.023 & 0.752 & 0.045 & 0.055 & -0.005 \\
\hline $\begin{array}{l}\text { Strong leader } \\
\text { bend rules }\end{array}$ & -0.002 & 0.362 & -0.028 & 0.125 & 0.027 \\
\hline $\begin{array}{l}\text { Immigrants good } \\
\text { for economy }(\mathrm{R})\end{array}$ & -0.049 & 0.172 & -0.593 & -0.035 & 0.057 \\
\hline $\begin{array}{l}\text { Immigrants harm } \\
\text { culture }\end{array}$ & -0.015 & 0.019 & 0.847 & -0.034 & 0.052 \\
\hline $\begin{array}{l}\text { Immigrants } \\
\text { increase crime }\end{array}$ & 0.011 & 0.096 & 0.698 & 0.023 & 0.017 \\
\hline $\begin{array}{l}\text { Born in } \\
\text { New Zealand }\end{array}$ & -0.035 & 0.037 & 0.071 & 0.750 & 0.045 \\
\hline $\begin{array}{l}\text { Grandparents born } \\
\text { in New Zealand }\end{array}$ & -0.003 & 0.018 & 0.008 & 0.964 & -0.058 \\
\hline $\begin{array}{l}\text { Have Māori } \\
\text { ancestry }\end{array}$ & 0.121 & -0.222 & -0.020 & 0.582 & 0.123 \\
\hline $\begin{array}{l}\text { Speak English } \\
\text { OR Māori }\end{array}$ & -0.006 & -0.041 & -0.018 & 0.013 & 0.637 \\
\hline $\begin{array}{l}\text { Follow New } \\
\text { Zealand customs }\end{array}$ & 0.003 & 0.113 & 0.061 & 0.022 & 0.621 \\
\hline
\end{tabular}

Note: Principal components, Varimax Rotation. $(R)$ signals that an item is reverse-worded. Loadings greater than 0.30 are presented in bold.

Source: New Zealand Election Study (2017). 
Table A3.2: Item content and factor loadings for the New Zealand Electoral Survey populism, authoritarianism and outgroups items

\begin{tabular}{|c|c|c|c|c|c|}
\hline & Authoritarian & Populist & Immigration & Nativism & $\begin{array}{l}\text { Cultural } \\
\text { Conformity }\end{array}$ \\
\hline $\begin{array}{l}\text { Strong leader } \\
\text { bends rules }\end{array}$ & 0.6834 & -0.1153 & -0.0155 & 0.1566 & -0.0672 \\
\hline $\begin{array}{l}\text { Young need strong } \\
\text { discipline }\end{array}$ & 0.6575 & 0.116 & 0.1009 & 0.1774 & 0.1067 \\
\hline Strong leaders better & 0.6463 & 0.183 & 0.0528 & 0.2406 & -0.0637 \\
\hline $\begin{array}{l}\text { Majority overrules } \\
\text { minority }\end{array}$ & 0.5646 & -0.0461 & 0.3329 & -0.101 & 0.3466 \\
\hline Death penalty & 0.5603 & 0.1084 & 0.251 & 0.114 & 0.0382 \\
\hline $\begin{array}{l}\text { Minorities should } \\
\text { adapt }\end{array}$ & 0.4662 & 0.0042 & 0.2506 & -0.2545 & 0.4892 \\
\hline $\begin{array}{l}\text { Politicians care } \\
\text { for rich }\end{array}$ & -0.0141 & 0.7907 & 0.1443 & 0.0349 & -0.005 \\
\hline $\begin{array}{l}\text { Government run big } \\
\text { interests }\end{array}$ & -0.0176 & 0.7404 & 0.1212 & 0.0725 & 0.0094 \\
\hline People decide & 0.0995 & 0.6709 & 0.0516 & 0.0325 & 0.0883 \\
\hline Politicians corrupt & 0.0655 & 0.5638 & 0.3176 & 0.1734 & -0.152 \\
\hline Public not experts & 0.2801 & 0.4568 & 0.046 & 0.1838 & 0.0992 \\
\hline $\begin{array}{l}\text { Compromise } \\
\text { a sell-out }\end{array}$ & 0.3477 & 0.4236 & 0.1302 & 0.0479 & 0.0861 \\
\hline $\begin{array}{l}\text { Immigrants increase } \\
\text { crime }\end{array}$ & 0.2154 & 0.1203 & 0.7645 & 0.1272 & 0.1054 \\
\hline $\begin{array}{l}\text { Immigrants good } \\
\text { for economy }\end{array}$ & -0.1004 & 0.1614 & 0.755 & 0.1781 & -0.121 \\
\hline $\begin{array}{l}\text { Immigrants harm } \\
\text { culture }\end{array}$ & 0.1725 & 0.1332 & 0.7539 & 0.2062 & 0.1562 \\
\hline $\begin{array}{l}\text { Important } \\
\text { New Zealand } \\
\text { grandparents }\end{array}$ & 0.1842 & 0.0518 & 0.241 & 0.7862 & 0.1477 \\
\hline $\begin{array}{l}\text { Important New } \\
\text { Zealand-born }\end{array}$ & 0.1865 & 0.0049 & 0.257 & 0.7504 & 0.2109 \\
\hline $\begin{array}{l}\text { Important Māori } \\
\text { ancestry }\end{array}$ & -0.0844 & 0.1777 & 0.0185 & 0.7293 & 0.0895 \\
\hline $\begin{array}{l}\text { Follow New Zealand } \\
\text { customs }\end{array}$ & 0.1434 & 0.0187 & 0.0085 & 0.3172 & 0.7172 \\
\hline $\begin{array}{l}\text { Speak English or } \\
\text { Māori }\end{array}$ & -0.1051 & 0.0157 & 0.0442 & 0.27 & 0.7452 \\
\hline
\end{tabular}

Note: Principal components, Varimax Rotation.

Source: New Zealand Election Study (2017). 
Table A3.3: Social and demographic correlates of populism and authoritarianism

\begin{tabular}{|c|c|c|}
\hline & Populist & Authoritarian \\
\hline \multicolumn{3}{|l|}{ (Post-war) } \\
\hline \multirow[t]{2}{*}{ Boomer } & $0.033^{\star \star \star}$ & $-0.074^{\star * *}$ \\
\hline & $(0.012)$ & $(0.012)$ \\
\hline \multirow[t]{2}{*}{ Generation X } & $0.045^{\star \star \star}$ & $-0.052^{\star \star \star}$ \\
\hline & $(0.014)$ & $(0.016)$ \\
\hline \multirow[t]{2}{*}{ Millennial } & $0.067^{\star \star \star}$ & $-0.055^{\star \star \star}$ \\
\hline & $(0.018)$ & $(0.016)$ \\
\hline \multirow[t]{2}{*}{ Generation Z } & 0.025 & $-0.135^{\star \star \star}$ \\
\hline & $(0.024)$ & $(0.037)$ \\
\hline \multirow[t]{2}{*}{ Female (Male) } & $0.017^{*}$ & $-0.047^{\star \star \star}$ \\
\hline & $(0.009)$ & $(0.009)$ \\
\hline \multirow[t]{2}{*}{ LGBT } & 0.015 & -0.033 \\
\hline & $(0.025)$ & $(0.023)$ \\
\hline \multirow[t]{2}{*}{ Māori } & $0.056^{\star \star \star}$ & -0.006 \\
\hline & $(0.011)$ & $(0.013)$ \\
\hline \multirow[t]{2}{*}{ Pasifika } & $0.073^{\star \star \star}$ & $0.078^{\star \star}$ \\
\hline & $(0.025)$ & $(0.037)$ \\
\hline \multirow[t]{2}{*}{ Asian } & 0.018 & $0.104^{\star \star \star}$ \\
\hline & $(0.016)$ & (0.019) \\
\hline \multicolumn{3}{|l|}{ (No assets) } \\
\hline \multirow[t]{2}{*}{ Low-risk assets } & -0.032 & -0.008 \\
\hline & $(0.021)$ & $(0.024)$ \\
\hline \multirow[t]{2}{*}{ High risk assets } & $-0.060^{\star \star \star}$ & -0.016 \\
\hline & $(0.022)$ & $(0.024)$ \\
\hline \multirow[t]{2}{*}{ Household income } & $-0.025^{\star \star \star}$ & $-0.007^{\star \star}$ \\
\hline & $(0.004)$ & $(0.004)$ \\
\hline \multirow[t]{2}{*}{ Religious } & 0.008 & $0.051^{\star * *}$ \\
\hline & $(0.010)$ & $(0.010)$ \\
\hline \multirow[t]{2}{*}{ Major urban } & -0.012 & $-0.042^{\star * \star}$ \\
\hline & $(0.009)$ & $(0.010)$ \\
\hline \multicolumn{3}{|l|}{ (Non-manual) } \\
\hline \multirow[t]{2}{*}{ Manual } & $0.046^{\star \star \star}$ & $0.028^{\star \star}$ \\
\hline & $(0.011)$ & $(0.011)$ \\
\hline
\end{tabular}


A POPULIST EXCEPTION?

\begin{tabular}{|l|c|c|}
\hline \multirow{2}{*}{ Farmer } & Populist & Authoritarian \\
\hline \multirow{2}{*}{ No Job } & -0.008 & 0.028 \\
\cline { 2 - 3 } & $(0.021)$ & $(0.021)$ \\
\hline \multirow{2}{*}{ University degree } & $0.047^{\star \star}$ & 0.018 \\
\cline { 2 - 3 } & $(0.021)$ & $(0.028)$ \\
\hline Constant & $-0.064^{\star \star \star}$ & $-0.137^{\star \star \star}$ \\
\cline { 2 - 3 } & $(0.011)$ & $(0.012)$ \\
\hline Observations & $0.566^{\star \star \star}$ & $0.617^{\star \star \star}$ \\
\hline R-squared & $(0.025)$ & $(0.024)$ \\
\hline
\end{tabular}

Note: Robust standard errors are given in parentheses.

${ }^{* \star *} p<0.01,{ }^{* \star} p<0.05,{ }^{*} p<0.1$

Source: New Zealand Election Study (2017). 
This text is taken from A Populist Exception?: The 2017 New Zealand General Election, edited by Jack Vowles and Jennifer Curtin, published 2020 by ANU Press, The Australian National University, Canberra, Australia.

doi.org/10.22459/PE.2020.03 